\title{
Pharmacist's recommendations of over- the-counter treatments for the common cold - analysis of prospective cases in Poland
}

Malgorzata Pietrusiewicz, Paulina Natalia Kopa-Stojak and Rafal Pawliczak

\begin{abstract}
Background: Common cold is a frequent illness in northern hemisphere between late autumn and early spring. Patients suffering from it frequently turn to pharmacists instead of physicians in order to receive medical advice and treatment. We studied its treatment advised by pharmacists in Poland, as well as evidence for the efficacy of their recommendations by utilizing a self-developed questionnaire and a study of existing literature.

Methods: The data were collected by 27 pharmacists who worked in four large network community pharmacies in Lodz, Poland. The study took place from December 2019 to February 2020. Data were recorded only if the patient asked for pharmacy counselling for over-the counter (OTC) products due to common cold self-diagnosis and a product was sold. Pharmacists' recommendations were compared with the results of a literature review of best evidence to determine appropriateness of the pharmacists' decisions.

Results: In four out of five cases the pharmacists recommended products contained paracetamol. In addition, in one out of three patient encounters they advised nasal decongestant, inosines and/or OTC mucolytics. There was a significant relationship between fever and recommendation frequency of some analgesics, inosines, mucolytics and sore throat products $(\mathrm{OR}>1, p<0.05)$; rhinorrhea and recommendation frequency of paracetamol, inosines, antihistamines and alpha-mimetics (OR $>1, p<0.05)$; cough and recommendation frequency of paracetamol, inosines, mucolytics and sore throat products $(\mathrm{OR}>1, p<0.05)$; and fatigue and recommendation frequency of paracetamol, acetylsalicylic acid, inosines and sore throat products $(\mathrm{OR}>1, p<0.05)$. The pharmacist recommendations were based on patients'symptoms, product price, pharmaceutical company promotion and the financial incentive. In many cases their recommendations were not in line with current best practice recommendations.
\end{abstract}

Conclusions: Our study suggests that the most common rationale for pharmacist recommendation on anti-common cold treatment was to take a "shotgun" approach. Pharmacists commonly made recommendations for products that lack strong evidence for efficacy (i.e. anti-viral agents) and are potentially unnecessary, based on presentation of the symptom. Reasons for this situation include lack of training, lack of time to evaluate the patient, lack of awareness of evidence as well as drug company marketing and financial incentives (i.e. fulfilling sale plans and target sale bonuses).

Trial registration: The study was a non-interventional, observational research trial. The study registration was not required.

*Correspondence: rafal.pawliczak@csk.umed.lodz.pl

Department of Immunopathology, Faculty of Medicine, Medical

University of Lodz, Lodz, Poland

(c) The Author(s) 2021. Open Access This article is licensed under a Creative Commons Attribution 4.0 International License, which permits use, sharing, adaptation, distribution and reproduction in any medium or format, as long as you give appropriate credit to the original author(s) and the source, provide a link to the Creative Commons licence, and indicate if changes were made. The images or other third party material in this article are included in the article's Creative Commons licence, unless indicated otherwise in a credit line to the material. If material is not included in the article's Creative Commons licence and your intended use is not permitted by statutory regulation or exceeds the permitted use, you will need to obtain permission directly from the copyright holder. To view a copy of this licence, visit http://creativecommons.org/licenses/by/4.0/. The Creative Commons Public Domain Dedication waiver (http://creativeco mmons.org/publicdomain/zero/1.0/) applies to the data made available in this article, unless otherwise stated in a credit line to the data. 
Keywords: Common cold, Over-the-counter medication, Respiratory infections, Pharmacist, Common cold treatment

\section{Background}

Common cold is a quite frequent illness in northern hemisphere in late autumn, winter and early spring months. Usually it is caused by rhinoviruses, coronaviruses and adenoviruses, as a single or combined upper airway infection. To most patients the infection is selflimiting and lasts approximately 10-12 days [1]. Interestingly, there are only a few national guidelines on common cold treatment [2-4]. In most countries patients suffering from this disease turn to pharmacists instead of physicians in order to receive medical advice and treatment. In one study $68 \%$ of patients consulted pharmacists and only $28 \%$ asked physicians for advice [5]. Therefore, the pharmacists' role in common cold treatment is crucial. The pharmacists' qualifications in counseling the patients with simple diseases differ internationally and are related to local law and pharmacist training. In some countries it focuses on advising treatment and is formalized as "pharmacist counselling". In Poland, the pharmacists' role is limited to selling prescribed and over-the-counter medications [6, 7]. The pharmacy profession describes their role in dispensing over-the counter (OTC) products as "selecting the best medication according to reported symptoms, while taking into account the safety and efficiency of the product". In addition, pharmacists should inform the patient about the product characteristic, dosage, possible side effects and drug interactions. If necessary, they should also remind the patients to consult physician [8-10]. The results of one large study suggested that $56 \%$ of responders trusted their pharmacists as drug consultants [11]. In some countries $73.8 \%$ of pharmacist counseling is related to common cold [12]. The number of OTC medications which might be used in common cold treatment is enormous and growing. It can be difficult and unsafe for an average patient to select the most appropriate ones. Most of them are soluble compositions of several drugs with different mechanisms of action, focusing on relieving selected common cold symptoms. In most cases they are combinations of nonsteroidal antiinflammatory drugs (NSAIDs), anti-histamines (usually old first generation), mucolytics, cough suppressants (central action only), and alpha1-mimetics [13-17]. To ensure fast onset of action, in most combinations soluble forms in powder are available. Moreover, several preparations with ascorbic acid combined with one or two aforementioned drugs are also available. Additionally, preparations with honey and herbal products are also used in common cold treatment [18-21]. Some of them have proven efficacy and safety, some not [18, 22-31]. All of them are available without prescription.

Therefore, it is of interest to analyze how patients choose OTC medications to treat common cold. There is no data available to show which medications are advised by pharmacists. Moreover, the motivation of pharmacists to advise specific medications is unknown.

\section{Methods}

\section{Study characteristic}

The study was performed in accordance with Article 2(c) of The Directive 2001/20/EC of the European Parliament and the Council as non-interventional, observational trials. The original, self-developed questionnaire was applied in four large network community pharmacies in Lodz, Poland, to all the patients who came for advice. Before starting this observational study, each pharmacist received guidelines (presented by a member of the research team) on how these consultations should be conducted. In addition, they also received recommendations on what questions should be raised during the consultation and how to fill in the data collection form in order to collect only the data valid for further analysis.

\section{Patients}

Only adult patients (aged 18years and over) were included in the study. The data were collected only if the patient asked for pharmacy counselling due to common cold self-diagnosis (based on the most common symptoms). If the patient was suffering from other symptoms or/and had a prescription for other medications, the data collection form was not filled and the data were not recorded. The following symptoms were recorded: cough, rhinitis, headache, fatigue or fever not exceeding $37.7^{\circ} \mathrm{C}$.

\section{Collected data}

The data collection form was filled by a pharmacist after a pharmacy counselling session resulting in dispensing an OTC medication to be utilized in common cold treatment. The data collection forms were collected from December 2019 to February 2020. They included data on age and sex of the pharmacy patient, number and type of common cold symptoms, type of products recommended by the pharmacist after each patient encounter and a rationale of the pharmacist's recommendation on the specific anti-common cold treatment in each individual case. The anti-common cold treatment recommendation section was divided into three sections (based on 
product formulation): soluble products (i.e. soluble powders in sachets, soluble tablets) including paracetamol, acetylsalicylic acid and magnesium metamizole; tablets/ capsules including paracetamol, acetylsalicylic acid, ibuprofen, pseudoephedrine, anti-viral agents, herbal and homeopathic products; and add-on treatment, such as alpha-mimetics (nasal spray and gels), mucolytics (syrups), anti-histamines and products for sore throat. English translation of the data collection form is presented as a supplementary material (see Supplementary file 1).

\section{Searching strategy and study selection}

To determine if the pharmacists' recommendations were consistent with best evidence or expert recommendation from clinical practice guidelines, we identified the existing evidence on these OTC products from a search of the Cochrane Library. The search was performed in May and June 2021, based on the terms: "common cold", "adult", "effective treatment". We focused on publications in English or Polish. For this analysis we chose systematic reviews and randomized clinical trials on the effectiveness of common cold treatment (for adults). Additional publications summarizing randomized controlled trials on treatment strategies were chosen from PubMed database (if Cochrane Library does not provide access to findings or only protocol was available). Supplementary file 2 summarizes the searching strategy. From each individual publication we extracted data on type of study, number of enrolled patients, treatment strategy and treatment effectiveness. Based on the data we prepared a summary of anti-common cold treatment options with beneficial effect, with potential/unclear effect or with no evidence of effect (see Supplementary Table 1). Finally, we compared the results obtained in our observational study with those from summarized clinical research on treatment effectiveness, then discussed the appropriateness of pharmacist recommendations of specific classes of anticommon cold products.

\section{Statistical analysis}

Statistical analysis was performed using Statistica 13.3 (StatSoft Inc., Tulsa, OK). The proportion of patients receiving each treatment is reported as a fraction of number of cases to all cases, and as percentage of patient encounters with anti-common cold medication recommendation. The Pearson's Chi square test was used to compare the frequency of receiving particular medications for patients reporting different symptoms. Odds ratio (with 95\% CI) was calculated to determine the relationship between presence of specific common cold symptoms and frequency of medication recommendation. The data with $p$-value $<0.05$ were considered statistically significant.

\section{Results}

\section{Characteristics of the patients}

Five hundred and two patient cases were examined. The majority of patients (53.1\%) were women. Almost 2/3 of patients were between 18 and 40 years old (64.7\%). Table 1 summarizes the demographical data.

The majority of patients $(280 / 502(55.8 \%))$ reported two out of 5 symptoms listed in the study questionnaire. Interestingly, 3/502 (0.6\%) patients did not identify any symptoms from the list and reported their self-diagnosis as "common cold", and 10/502 (2\%) patients identified all 5 symptoms from the list (Fig. 1a).

The most frequently reported symptom was headache, present in $389 / 502(77.5 \%)$ cases, followed by rhinorrhea 308/502 (61.4\%) cases, and cough 177/502 (35.1\%). Fatigue and elevated body temperature were present in $165 / 502(32.9 \%)$ and $140 / 502(27.9 \%)$ patients, respectively (Fig. 1b).

\section{Class of anti-common cold treatment mostly recommended by pharmacists}

Soluble form of medication was recommended in $339 / 502(67.5 \%)$ cases, where the most frequent were a combination of paracetamol, guaifenesin and phenylephrine HCL (utilized in 67/502 (13.3\%) patient encounters), paracetamol, ascorbic acid and phenylephrine HCL (advised in 65/502 (12.9\%) patient encounters), or products composed of paracetamol, phenylephrine HCL and pheniramine maleate (recommended in 62/502 (12.4\%) patient encounters), and a simple combination of paracetamol and phenylephrine HCL (advised in 59/502 (11.8\%) patient encounters) (Fig. 2a).

Oral tablets/capsule medications were advised in $404 / 502(80.5 \%)$ cases, where the most frequent were inosine pranobex (recommended in 182/502 (36.3\%) patient encounters), and a combination of paracetamol, pseudoephedrine and dextromethorphan hydrobromide (advised in 80/502 (15.9\%) cases). Tablets containing a combination of ibuprofen and pseudoephedrine were recommended in 72/502 (14.3\%) cases (Fig. 2b).

Add-on treatment was recommended in 352/502 (69.7\%) patient encounters, mostly included: nasal spray

Table 1 Patients characteristics

\begin{tabular}{ll}
\hline Sex $[n ; \%]$ & \\
Female & $264(53.1 \%)$ \\
Male & $233(46.9 \%)$ \\
Age $[n ; \%]$ & \\
$18-40$ years & $325(64.7 \%)$ \\
$41-60$ years & $145(28.9 \%)$ \\
$61-90$ years & $32(6.4 \%)$ \\
\hline
\end{tabular}




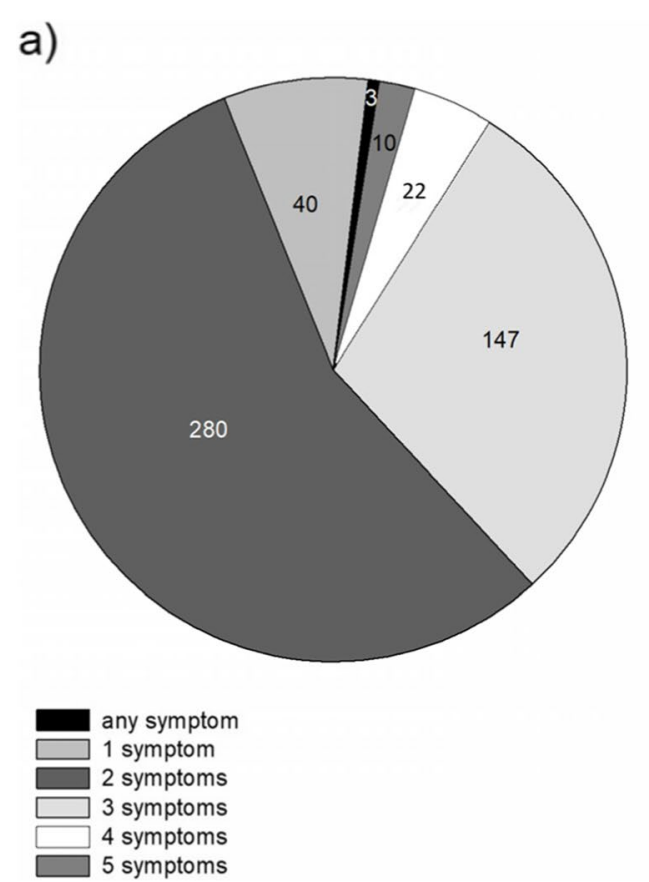

b)

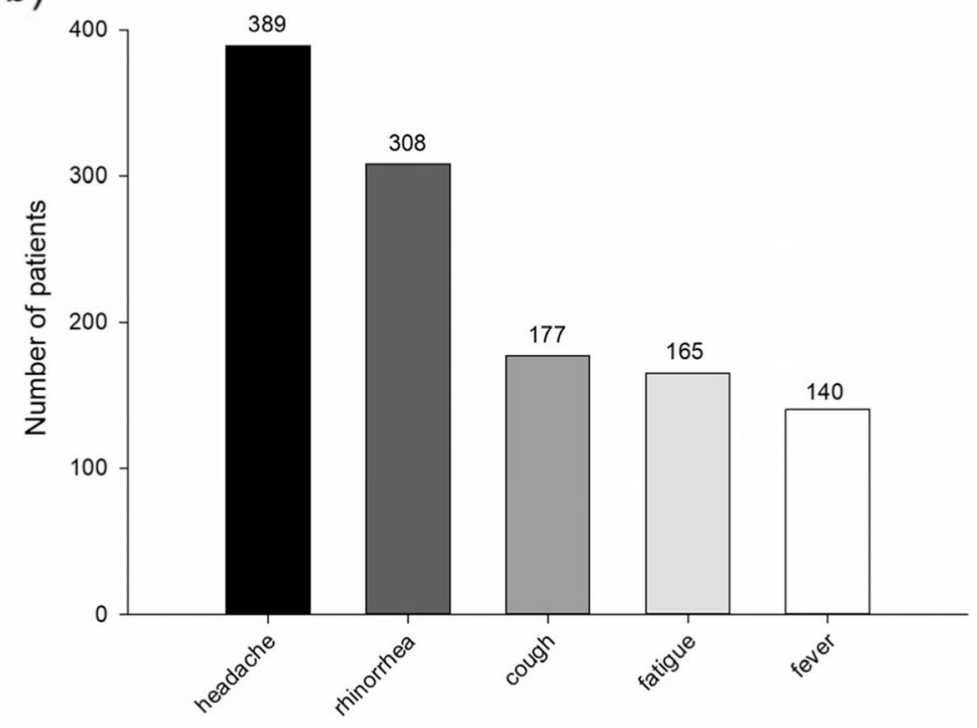

Fig. 1 Common cold symptoms reported by the patients. Common cold symptoms reported in 502 patient encounters during pharmacists' recommendations of OTC products (a). Frequency of common cold symptoms reported by patients $(\mathbf{b})$. The results are presented as raw numbers of patient encounters with anti-common cold medication recommendation

containing alpha-mimetics (i.e. xylometazoline, oxymetazoline HCL) utilized in 194/502 (38.6\%) cases, mucolytics (such as acetylcysteine, ambroxol HCL and bromohexine $\mathrm{HCL}$ ) advised in $133 / 502(26.5 \%)$ cases or antibacte$\mathrm{rial} /$ antifungal agents for sore throat, recommended in 67/502 (13.3\%) patient encounters (Fig. 2c).

The pharmacists' recommendations for anti-common cold treatment varied between one to seven different medications. The most frequently advised combinations consisted of three or two different products, in 184/502 (36.7\%) and 150/502 (29.9\%) patient encounters, respectively. A single anti-common cold medication was recommended in 77/502 (15.3\%) cases. In 34/502 (6.8\%) cases 4 products, in $28 / 502(5.6 \%)$ cases 5 products, in $25 / 502$ (5\%) cases 6 products and in 4/502 (0.7\%) cases 7 different medications were recommended (Table 2).

The most frequent pharmacist recommendation was a combination of 3 different products - one soluble, one tablet/capsule formulation and one add-on common cold medication, reported in 112/502 (22.3\%) patient encounters. Here, the most frequent combination comprised paracetamol with anti-viral product and with mucolytics, recommended in 22/112 (19.6\%) cases. The second most popular combination comprised paracetamol with anti-viral agents and alpha-mimetics, advised in $16 / 122(14.3 \%)$ patient encounters. The third most frequent recombination (advised in 58/502 (11.6\%) cases) comprised a soluble medication with add-on anti-common cold treatment (i.e. ibuprofen/pseudoephedrine with alpha-mimetics or paracetamol with alpha-mimetics), and the fourth most frequent recombination was a combination of one medication in tablet formulation with add-on treatment (advised in 53/502 patient encounters) (Table 2).

\section{Rationale of pharmacist recommendations for anti-common cold treatment}

The reasons behind advising specific medication by pharmacists in order to treat common cold are always unspecified. In our study, in 240/502 (47\%) patient encounters the pharmacists declared that their approach to patient treatment was based solely on patients' complaints, history and analysis of the patient's needs. Moreover, in 108/502 (21.5\%) patient encounters the pharmacists declared that the price of the drug was a major factor. In addition, in 80/502 (15.9\%) cases the pharmacists advised a common cold medication basing on their belief in the efficacy of the drug in current clinical situation. In 75/502 (14.9\%) patient encounters the pharmacists declared that a major reason for advising a specific medication was a marketing approach from inside the pharmacy or outside, for financial reward or other benefits paid by pharmaceutical industry or its representatives (Fig. 3). 
a)

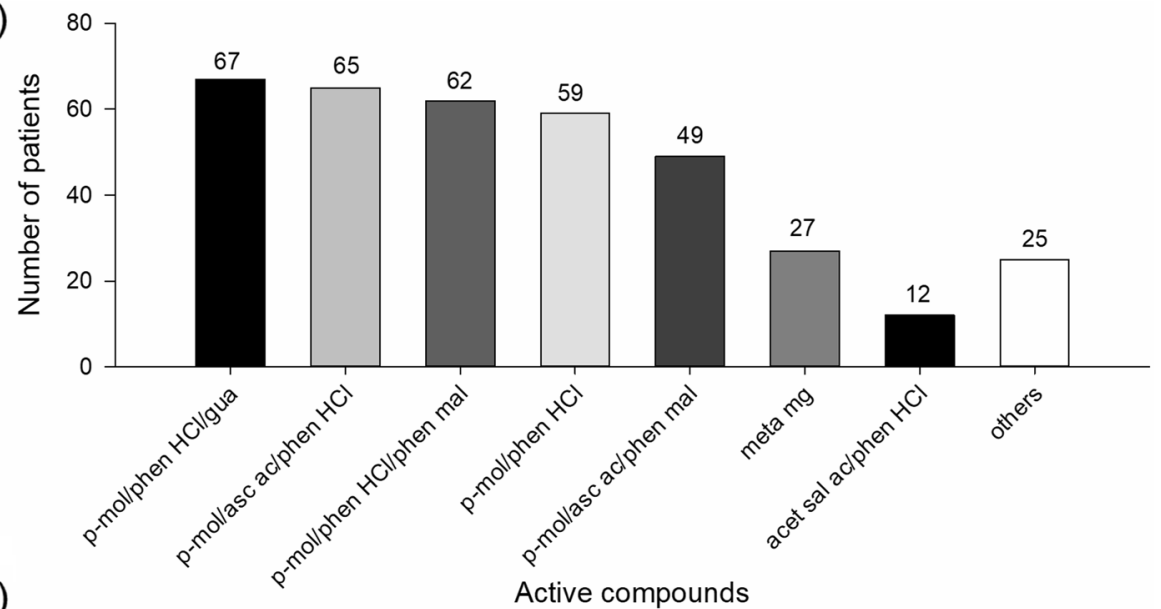

b)

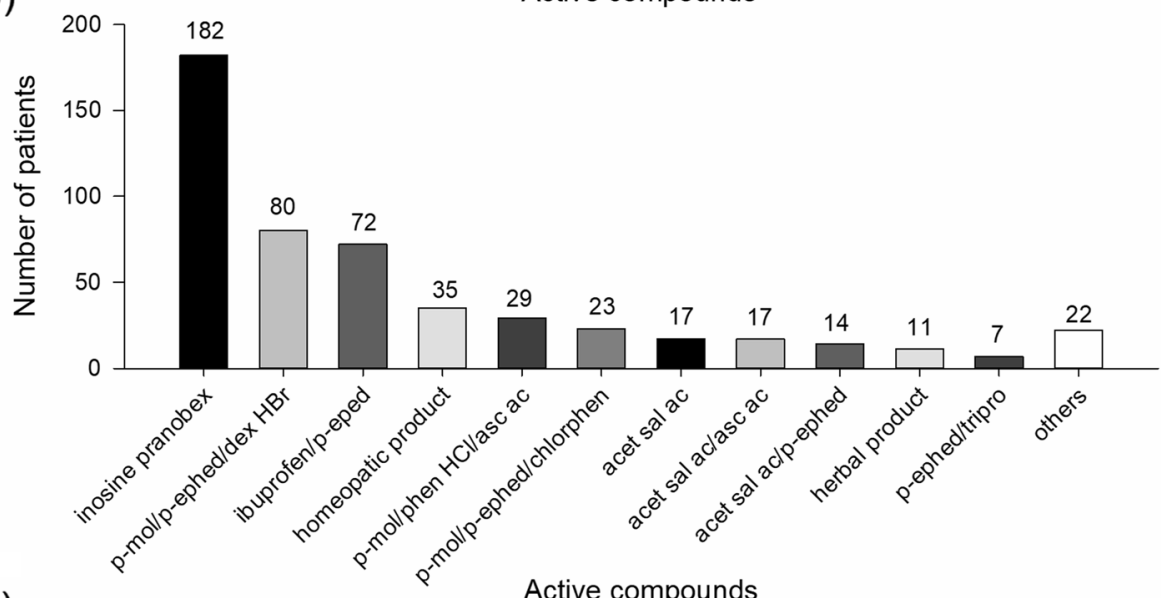

c)

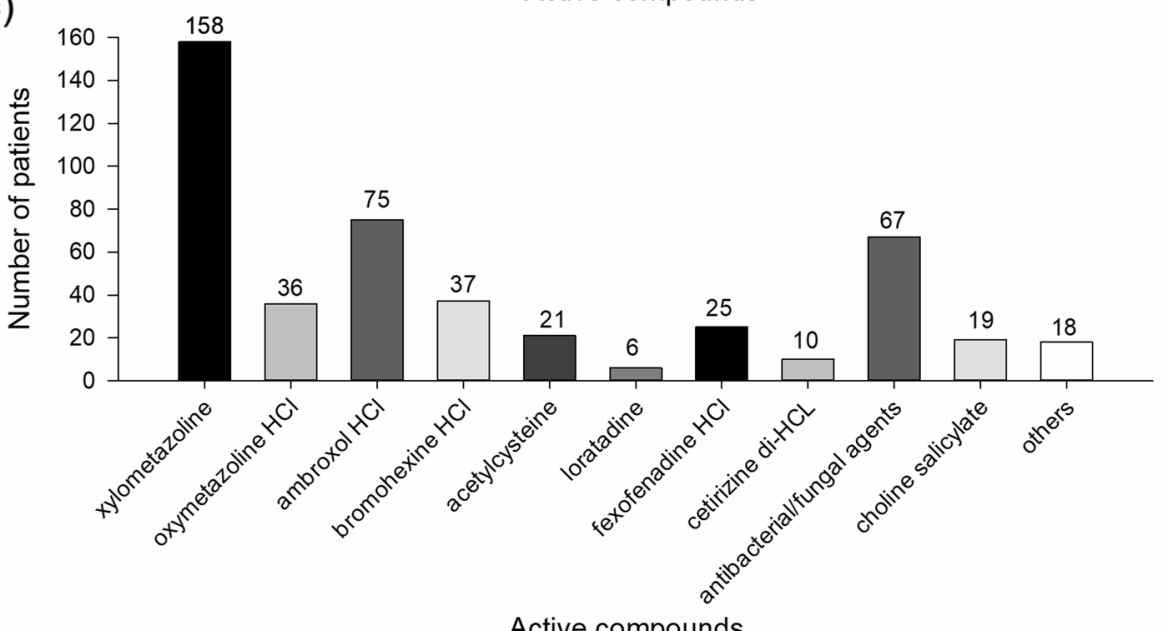

Active compounds

Fig. 2 Anti-common cold treatment recommendations. Frequency of recommending soluble formulations (a), tablets/capsules (b), or add-on (c) OTC anti-common cold products by the pharmacists in 502 patient encounters. The results are presented as raw numbers of patient encounters with anti-common cold medication recommendation. Abbreviations: acet sal ac - acetylsalicylic acid; asc ac - ascorbic acid; chlorphen chlorpheniramine; dex $\mathrm{HBr}$ - dextromethorphan hydrobromide; qua - guaifenesin; meta mg - metamizole magnesium; $p$-mol - paracetamol; phen $\mathrm{HCl}$ - phenylephrine $\mathrm{HCl}$; phen mal - pheniramine maleate; -ephed - pseudoephedrine; tripro - triprolidine 
Table 2 Quantity of anti-common cold medications recommended by the pharmacists

\begin{tabular}{|c|c|c|c|}
\hline \multirow{2}{*}{$\begin{array}{l}\text { Number of } \\
\text { medications }\end{array}$} & \multirow{2}{*}{$\begin{array}{l}\begin{array}{l}\text { Quantity of } \\
\text { recommendations } \\
\text { [n;\%] }^{\mathbf{b}}\end{array} \\
77(15.3 \%)\end{array}$} & \multicolumn{2}{|c|}{$\begin{array}{l}\text { Combinations of anti-common cold } \\
\text { treatment }[\mathrm{n} ; \%]^{\mathrm{c}}\end{array}$} \\
\hline & & 1 soluble & $32(6.4 \%)$ \\
\hline & & 1 tablets & $43(8.6 \%)$ \\
\hline & & 1 add-on & $2(0.4 \%)$ \\
\hline \multirow[t]{5}{*}{2} & $184(36.7 \%)$ & 2 tablets & $28(5.6 \%)$ \\
\hline & & 2 add-on & $1(0.1 \%)$ \\
\hline & & 1 soluble/1 add-on & $58(11.6 \%)$ \\
\hline & & 1 soluble/1 tablets & $44(8.8 \%)$ \\
\hline & & 1 tablets/1 add-on & $53(10.6 \%)$ \\
\hline \multirow[t]{6}{*}{3} & $150(29.9 \%)$ & 3 add-on & $1(0.1 \%)$ \\
\hline & & 1 soluble/2 add-on & $6(1.2 \%)$ \\
\hline & & 1 soluble/2 tablets & $1(0.1 \%)$ \\
\hline & & 1 tablets/2 add-on & $5(1 \%)$ \\
\hline & & 1 add-on/2 tablets & $25(5 \%)$ \\
\hline & & $\begin{array}{l}1 \text { soluble/1 tablets/1 } \\
\text { add-on }\end{array}$ & $112(22.3 \%)$ \\
\hline \multirow[t]{5}{*}{4} & $34(6.8 \%)$ & 1 tablets/3 add-on & $1(0.1 \%)$ \\
\hline & & 2 tablets/2 add-on & $4(0.7 \%)$ \\
\hline & & $\begin{array}{l}1 \text { soluble/1 tablets/2 } \\
\text { add-on }\end{array}$ & $24(4.8 \%)$ \\
\hline & & $\begin{array}{l}1 \text { soluble/2 tablets/1 } \\
\text { add-on }\end{array}$ & $4(0.7 \%)$ \\
\hline & & $\begin{array}{l}2 \text { soluble/1 tablets/1 } \\
\text { add-on }\end{array}$ & $1(0.1 \%)$ \\
\hline \multirow[t]{4}{*}{5} & $28(5.6 \%)$ & $\begin{array}{l}1 \text { soluble/2 tablets/2 } \\
\text { add-on }\end{array}$ & $14(2.8 \%)$ \\
\hline & & $\begin{array}{l}2 \text { soluble/1 tablets } / 2 \\
\text { add-on }\end{array}$ & $3(0.6 \%)$ \\
\hline & & $\begin{array}{l}2 \text { soluble/2 tablets } / 1 \\
\text { add-on }\end{array}$ & $1(0.1 \%)$ \\
\hline & & $\begin{array}{l}1 \text { soluble/1 tablets } / 3 \\
\text { add-on }\end{array}$ & $10(2 \%)$ \\
\hline \multirow[t]{4}{*}{6} & $25(5 \%)$ & $\begin{array}{l}1 \text { soluble/1 tablets } / 4 \\
\text { add-on }\end{array}$ & $1(0.1 \%)$ \\
\hline & & $\begin{array}{l}1 \text { soluble/2 tablets } / 3 \\
\text { add-on }\end{array}$ & $6(1.2 \%)$ \\
\hline & & $\begin{array}{l}2 \text { soluble/1 tablets } / 3 \\
\text { add-on }\end{array}$ & $1(0.1 \%)$ \\
\hline & & $\begin{array}{l}2 \text { soluble/2 tablets } / 2 \\
\text { add-on }\end{array}$ & $17(3.4 \%)$ \\
\hline \multirow[t]{2}{*}{7} & $4(0.7 \%)$ & $\begin{array}{l}2 \text { soluble/2 tablets } / 3 \\
\text { add-on }\end{array}$ & $2(0.4 \%)$ \\
\hline & & $\begin{array}{l}2 \text { soluble/3 tablets } / 2 \\
\text { add-on }\end{array}$ & $2(0.4 \%)$ \\
\hline
\end{tabular}

\footnotetext{
${ }^{a}$ Number of recommended anti-common cold medications (presented as a raw number)

b Number of patient encounters where a given number of medications were recommended, presented as raw numbers and, in brackets, as percentage of total 502 patient encounters

c Anti-common cold treatment was divided into three sections: soluble products including paracetamol, acetylsalicylic acid and magnesium metamizole; tablets/capsules including paracetamol, acetylsalicylic acid, ibuprofen, pseudoephedrine, anti-viral agents, herbal and homeopathic products; and add-on treatment, such as alpha-mimetics, mucolytics, antihistamines and products for sore throat. Data presented as raw numbers of the patient encounters with anti-common cold medication recommendation and as percentage of the pharmacists' recommendations in 502 patient encounters
}

Anti-common cold treatment recommendations based on the selected clinical symptoms

\section{Headache}

It was of interest to analyze if specific common cold symptoms drive advice towards causative OTC treatment. Headache reported by patients did not deliver any specific treatment. More than two-thirds of patients with headache received a combination of medications containing NSAIDs. In 150/389 (38.6\%) cases they received alpha-mimetics, and in 27/389 (6.9\%) cases an old, first generation antihistamine (Table 3).

\section{Fever}

There was a statistical significance between fever complaints and utilization of various forms of NSAIDs $(r=0.69$ $p<0.05)$. A soluble, fast-acting form was the most common, as compared to tablets $(122 / 140(87.5 \%)$ cases vs. $64 / 140$ (45.7\%) cases; $p<0.05$, respectively). In $68 / 140$ (48.6\%) cases, the pharmacists recommended anti-viral and one-third of patients with fever took mucolytics (advised in 49/140 (35\%) cases). In addition, there was a relationship between patient encounters with reported fever and recommendation frequency for acetylsalicylic acid, magnesium metamizole, paracetamol, inosines, mucolytics and sore throat products $(\mathrm{OR}>1, p<0.05)$ (Table 3$)$.

\section{Stuffy nose}

Alpha-mimetics in nasal spray formulations were used in $166 / 308(53.8 \%)$ patients, with rhinorrhea as the dominant symptom. The most common medication included a $0.1 \%$ xylometazoline solution in nasal spray $(100 / 308(32.4 \%)$ cases; $r=0.999 ; p<0.05)$. The gel form of xylometazoline was the second most frequent nasal preparation, used in $38 / 308(12.3 \%)$ patients $(r=0.993$; $p<0.05)$. In addition, in $54 / 308$ cases the pharmacists recommended a combination of paracetamol with phenylephrine HCL, and inosines were advised in 90/308 (29.2\%) cases. There was a relationship between patient encounters with reported stuffy nose and recommendation frequency of xylometazoline, paracetamol, antihistamines and inosines $(\mathrm{OR}>1, p<0.05)$ (Table 3$)$.

\section{Cough}

Cough is one of the most widespread symptoms of common cold. Almost two-thirds of patients with cough received medications with soluble paracetamol and mucolytics (123/177 (69.4\%) cases and 105/177 (59.3\%) cases, respectively). In addition, almost half of them received products containing paracetamol (62/177 (35\%) cases) or acetylsalicylic acid (21/177 (11.9\%) cases) in the form of tablets/capsules. In addition, over one-third of patients received anti-viral products, alpha-mimetics or medications for sore throat $(81 / 177$ 


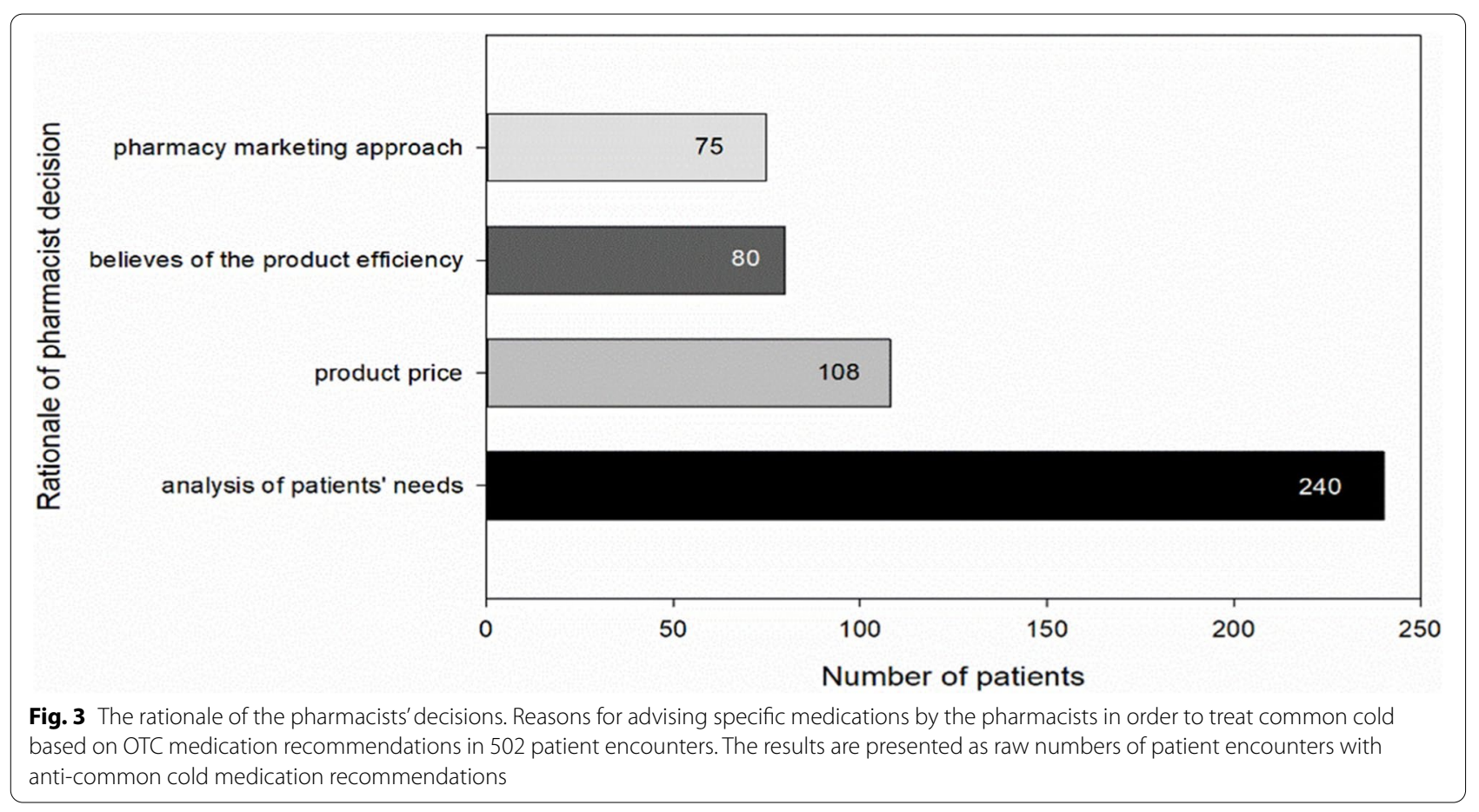

(45.7\%) cases, 53/177 (29.9\%) cases and 47/177 (26.5\%) cases, respectively). There was a significant relationship between cases with reported cough and recommendation frequency for products containing inosines, mucolytics and chlorchinaldol (OR $>1, p<0.05)$ (Table 3).

\section{Fatigue}

Patients who reported fatigue as the main common cold symptom received products containing soluble paracetamol $(107 / 165(64.8 \%)$ cases) and anti-viral products (in $73 / 165$ (44.3\%) cases). Almost one-third of patients with fatigue received alpha mimetics (recommended in 44/165 (26.6\%) cases), mucolytics (recommended in 50/165 (30.4\%) cases) and medications for sore throat (recommended in $49 / 165$ (29.8\%) cases). Interestingly, there was a relationship between cases with reported fatigue and recommendation frequency of acetylsalicylic acid, paracetamol, inosines and products for sore throat $(\mathrm{OR}>1, p<0.05)$ (Table 3). Patients with common cold frequently suffer from only a limited number of main symptoms, which might drive them to express a precise need for medication. To assess the pharmacist approach to these needs we analyzed the treatment approach in the most common combinations of symptoms.

\section{Anti-common cold treatment recommendations of the most common symptom combinations}

Paracetamol in soluble formulation was most frequently received by the patients suffering from: headache and fever (in 11/17 (64.7\%) patients), fever and cough (in 7/13
(53.8\%) patients), fever and rhinitis (in 11/12 (91.7\%) patients), fever and fatigue (in 6/7 (85.7\%) patients), cough and rhinitis (in $8 / 9(88.9 \%)$ patients), or cough and fatigue (in $10 / 13(76.9 \%)$ patients). Patients complaining about headache and rhinorrhea mostly received rhinorrhea medications (in 92/147 (62.3\%) patients). Among patients with headache and cough as a main symptoms, the most frequent recommendations were cough medications (in $21 / 26(80.8 \%)$ patients), and for these with headache and fatigue - inosines (in 16/34 (47.1\%) patients). All patients with rhinitis and fatigue received paracetamol in soluble formulation and rhinorrhea medications (Table 4).

\section{Discussion}

To our best knowledge, this is the first study assessing pharmacist counselling focused on class, types and formulas of medication advised for common cold treatment in Poland. A similar study to ours was published on counselling efficacy and communication, where the counselling was found to be suboptimal. However, in Mináriková et al. the study mainly focused on the counselling process, rather than the appropriateness of product recommendations [6]. Every adult experiences 2-3 episodes of cold annually. In children this frequency is much higher, up to 5-6 episodes per year [32, 33].

\section{Comparison with existing literature on best practice}

A vast majority of pharmacists in our study (almost 9 out of 10 patient encounters) recommended medications 
Table 3 Products advised by the pharmacists for a selected clinical symptoms of common cold

\begin{tabular}{|c|c|c|}
\hline Symptom & Patients receiving medications $[\mathrm{n}]$ & Statistics \\
\hline \multirow[t]{11}{*}{ headache } & paracetamol [329] & $p>0.05$ \\
\hline & acetylsalicylic acid [41] & \\
\hline & magnesium metamizole [15] & \\
\hline & inosines [140] & \\
\hline & homeopathics [17] & \\
\hline & herbal products [5] & \\
\hline & pseudoephedrine [67] & \\
\hline & alpha-mimetics [150] & \\
\hline & anti-histamines [27] & \\
\hline & mucolytics [78] & \\
\hline & sore throat products [53] & \\
\hline \multirow[t]{11}{*}{ fever } & paracetamol [127] & for paracetamol with ascorbate acid and pheniramine maleate $\mathrm{OR}=2.105,95 \% \mathrm{Cl} 1.152-3.843 ; p=0.022$ \\
\hline & acetylsalicylic acid [25] & $\begin{array}{l}\text { for acetylsalicylic acid } \mathrm{OR}=3.901,95 \% \mathrm{Cl} 1.445-10.463 ; p=0.009 ; \text { for acetylsalicylic acid with phenylephrine } \mathrm{HCL} \\
\text { and chlorphenamine } \mathrm{OR}=3.758,95 \% \mathrm{Cl} 1.172-12.045 ; p=0.04\end{array}$ \\
\hline & magnesium metamizole [14] & for magnesium metamizole $\mathrm{OR}=2.983,95 \% \mathrm{Cl} 1.365-6.52 ; p=0.008$ \\
\hline & inosines [68] & for inosines $\mathrm{OR}=4.754,95 \% \mathrm{Cl} 1.832-12.34 ; p=0.001$ \\
\hline & homeopathics [14] & $p>0.05$ \\
\hline & herbal products [8] & \\
\hline & pseudoephedrine [17] & \\
\hline & alpha-mimetics [54] & \\
\hline & anti-histamines [7] & \\
\hline & mucolytics [49] & for ambroxol HCL OR=2.664,95\%Cl 1.353-5.242; $p=0.006$ \\
\hline & sore throat products [46] & $\begin{array}{l}\text { for choline salicylate } \mathrm{OR}=3.017,95 \% \mathrm{Cl} 1.199-7.591, p=0.028 \text {; for chlorchinaldol } \mathrm{OR}=3.222,95 \% \mathrm{Cl} 1.491-6.96 \\
p=0.004 \text {; for amylmetacresol with levomenthol and 2,4-dichlorobenzol } \mathrm{OR}=3.677,95 \% \mathrm{Cl} 1.515-8.933, p=0.005\end{array}$ \\
\hline \multirow[t]{11}{*}{ rhonorrhea } & paracetamol [265] & for paracetamol with phenylephrine $\mathrm{HCL} O R=8.036,95 \% \mathrm{Cl} 3.154-20.477, p<0.001$ \\
\hline & acetylsalicylic acid [28] & $p>0.05$ \\
\hline & magnesium metamizole [4] & \\
\hline & inosines $[90]$ & for inosines $\mathrm{OR}=10.509,95 \% \mathrm{Cl} 4.153-26.591, p<0.001$ \\
\hline & homeopathics [13] & $p>0.05$ \\
\hline & herbal products [5] & \\
\hline & pseudoephedrine [72] & \\
\hline & alpha-mimetics [166] & 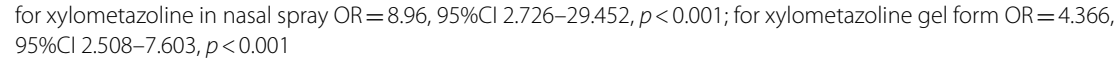 \\
\hline & anti-histamines [28] & for fexofenadine $\mathrm{HCL} O R=4.987,95 \% \mathrm{Cl} 1.446-16.95, p=0.009$ \\
\hline & mucolytics [52] & $p>0.05$ \\
\hline & sore throat products [41] & \\
\hline \multirow[t]{11}{*}{ cough } & paracetamol [185] & $\begin{array}{l}\text { for paracetamol, ascorbic acid and phenylephrine } \mathrm{HCL} O \mathrm{OR}=5.667,95 \% \mathrm{Cl} 1.132-28.378, p=0.046 \text {; for paraceta- } \\
\text { mol, ascorbic acid and pheniramine maleate } \mathrm{OR}=2.261,95 \% \mathrm{Cl} 1.242-4.092, p=0.01 \text {; for paracetamol, ascorbic } \\
\text { acid and phenylephrine } \mathrm{HCL} \mathrm{OR}=4.515,95 \% \mathrm{Cl} 1.821-11.196, p<0.001 \text {; for paracetamol, phenylephrine } \mathrm{HCL} \text { and } \\
\text { ascorbic acid (in a form of tablets) } \mathrm{OR}=2.771,95 \% \mathrm{Cl} 1.292-5.945, p=0.012\end{array}$ \\
\hline & acetylsalicylic acid [27] & $p>0.05$ \\
\hline & magnesium metamizole [7] & \\
\hline & inosines [81] & for inosines $\mathrm{OR}=1.812,95 \% \mathrm{Cl} 1.175-2.794, p=0.009$ \\
\hline & homeopathics [15] & $p>0.05$ \\
\hline & herbal products [3] & \\
\hline & pseudoephedrine [14] & \\
\hline & alpha-mimetics [53] & \\
\hline & anti-histamines [14] & \\
\hline & mucolytics [105] & $\begin{array}{l}\text { for bromohexide } \mathrm{HCL} O R=18.391,95 \% \mathrm{Cl} 6.396-52.877, p<0.001 \text {; of ambroxol } \mathrm{HCL} \mathrm{OR}=9.57,95 \% \mathrm{Cl} 3.869- \\
23.671, p<0.001 \text {; of acetylcysteine } \mathrm{OR}=8.527,95 \% \mathrm{Cl} 2.822-25.759, p<0.001\end{array}$ \\
\hline & sore throat products [47] & for chlorchinaldol OR=4.222, 95\%Cl 1.867-9.546, $p<0.001$ \\
\hline
\end{tabular}


Table 3 (continued)

\begin{tabular}{|c|c|c|}
\hline Symptom & Patients receiving medications $[\mathrm{n}]$ & Statistics \\
\hline \multirow[t]{11}{*}{ fatigue } & paracetamol [169] & $\begin{array}{l}\text { for paracetamol with ascorbic acid and phenylephrine } \mathrm{HCL} O R=3.378,95 \% \mathrm{Cl} 1.431-7.979, p=0.007 \text {; for par- } \\
\text { acetamol with phenylephrine } \mathrm{HCL} \text { and ascorbic acid (in form of tablets) } \mathrm{OR}=2.307,95 \% \mathrm{Cl} 1.086-4.902, p=0.043 \text {; } \\
\text { for paracetamol with pseudoephedrine and dextromethorphan } \mathrm{OR}=1.917,95 \% \mathrm{Cl} 1.131-3.252, p=0.021\end{array}$ \\
\hline & acetylsalicylic acid [26] & $\begin{array}{l}\text { for acetylsalicylic acid with pseudoephedrine } O R=3.831,95 \% \mathrm{Cl} 1.263-11.62, p=0.024 \text {; for acetylsalicylic acid } \\
\text { with ascorbic acid } \mathrm{OR}=3.041,95 \% \mathrm{Cl} 1.136-8.141, p=0.04\end{array}$ \\
\hline & magnesium metamizole [5] & $p>0.05$ \\
\hline & inosines [73] & for inosines $\mathrm{OR}=1.715,95 \% \mathrm{Cl} 1.107-2.657, p=0.021$ \\
\hline & homeopathics [12] & $p>0.05$ \\
\hline & herbal products [2] & \\
\hline & pseudoephedrine [10] & \\
\hline & alpha-mimetics [44] & \\
\hline & anti-histamines [8] & \\
\hline & mucolytics [50] & \\
\hline & sore throat products [49] & $\begin{array}{l}\text { for choline salicylate } \mathrm{OR}=4.718,95 \% \mathrm{Cl} 1.76-12.65, p=0.002 \text {; for amylmetacresol with levomenthol and } \\
\text { 2,4-dichlorobenzol } \mathrm{OR}=3.517,95 \% \mathrm{Cl} 1.428-8.664, p=0.008\end{array}$ \\
\hline
\end{tabular}

Table 4 Treatment of the most common cold symptom combinations

\begin{tabular}{|c|c|c|c|c|c|c|c|c|c|}
\hline \multirow[t]{2}{*}{ Symptoms [n] } & \multicolumn{9}{|c|}{ Patients receiving medications [n;\%] } \\
\hline & $\begin{array}{l}\text { paracetamol } \\
\text { (soluble) }\end{array}$ & $\begin{array}{l}\text { paracetamol } \\
\text { (tablets) }\end{array}$ & $\begin{array}{l}\text { acetylsalicylic } \\
\text { acid }\end{array}$ & inosines & ibuprofen & $\begin{array}{l}\text { herbal and } \\
\text { homeopathic } \\
\text { medications }\end{array}$ & $\begin{array}{l}\text { rhinorrhea } \\
\text { medication }^{a}\end{array}$ & $\begin{array}{l}\text { cough } \\
\text { medications }\end{array}$ & $\begin{array}{l}\text { sore throat } \\
\text { medications }\end{array}$ \\
\hline $\begin{array}{l}\text { headache } \\
\text { rhinorrhea } \\
\text { (147) }\end{array}$ & $79(53.7 \%)$ & $24(16.3 \%)$ & $6(4.1 \%)$ & $29(19.7 \%)$ & $45(30.6 \%)$ & $4(2.7 \%)$ & $92(62.3 \%)$ & $2(1.4 \%)$ & $2(1.4 \%)$ \\
\hline $\begin{array}{l}\text { headache } \\
\text { fatigue (34) }\end{array}$ & $14(41.2 \%)$ & $11(32.4 \%)$ & $9(26.5 \%)$ & $16(47.1 \%)$ & $0(0 \%)$ & $0(0 \%)$ & $2(5.9 \%)$ & $3(8.8 \%)$ & $6(17.6 \%)$ \\
\hline $\begin{array}{l}\text { headache } \\
\text { cough (26) }\end{array}$ & $15(57.7 \%)$ & $11(42.3 \%)$ & $4(15.4 \%)$ & $11(42.3 \%)$ & $0(0 \%)$ & $3(11.5 \%)$ & $6(23.1 \%)$ & $21(80.8 \%)$ & $2(7.7 \%)$ \\
\hline $\begin{array}{l}\text { headache } \\
\text { fever (17) }\end{array}$ & $11(64.7 \%)$ & $4(23.5 \%)$ & $3(17.65)$ & $9(52.9 \%)$ & $0(0 \%)$ & $4(23.5 \%)$ & $4(23.5 \%)$ & $5(29.4 \%)$ & $7(41.2 \%)$ \\
\hline $\begin{array}{l}\text { cough } \\
\text { fatigue (13) }\end{array}$ & $10(76.9 \%)$ & $5(38.5 \%)$ & $1(7.7 \%)$ & $5(38.5 \%)$ & $0(0 \%)$ & $1(7.7 \%)$ & $3(23.1 \%)$ & $9(69.2 \%)$ & $3(23.1 \%)$ \\
\hline $\begin{array}{l}\text { fever } \\
\text { cough (13) }\end{array}$ & $7(53.8 \%)$ & $6(46.2 \%)$ & $3(23.1 \%)$ & $5(38.5 \%)$ & $1(7.7 \%)$ & $3(23.1 \%)$ & $5(38.5 \%)$ & $4(30.8 \%)$ & $6(46.2 \%)$ \\
\hline $\begin{array}{l}\text { fever } \\
\text { rhinorrhea (12) }\end{array}$ & 11 (91.7\%) & $5(41.7 \%)$ & $3(25 \%)$ & $7(58.3 \%)$ & $1(8.3 \%)$ & $4(33.3 \%)$ & $10(83.3 \%)$ & 10 (83.3\%) & $4(25 \%)$ \\
\hline $\begin{array}{l}\text { rhinorrhea } \\
\text { cough (9) }\end{array}$ & $8(88.9 \%)$ & $0(0 \%)$ & $2(22.2 \%)$ & $5(55.6 \%)$ & $1(11.1 \%)$ & $1(11.1 \%)$ & $4(44.4 \%)$ & $7(77.8 \%)$ & $1(11.1 \%)$ \\
\hline $\begin{array}{l}\text { fever } \\
\text { fatigue (7) }\end{array}$ & $6(85.7 \%)$ & $1(14.3 \%)$ & $3(42.9 \%)$ & $1(14.3 \%)$ & $1(14.3 \%)$ & $1(14.3 \%)$ & $1(14.3 \%)$ & $2(28.6 \%)$ & $1(14.3 \%)$ \\
\hline $\begin{array}{l}\text { rhinorrhea } \\
\text { fatigue (2) }\end{array}$ & $2(100 \%)$ & $0(0 \%)$ & $1(50 \%)$ & $0(0 \%)$ & $1(50 \%)$ & $0(0 \%)$ & $2(100 \%)$ & $0(0 \%)$ & $0(0 \%)$ \\
\hline
\end{tabular}

The mostly recommended anti-common cold medications for given symptoms are marked in bold

a Alpha-mimetics and anti-histamines

containing a combination of paracetamol with additional active compounds against common cold symptoms. The amount of paracetamol recommendations exceeded these for NSAIDs (advised in over one quarter of cases). Analysis of clinical trials shows that analgesics effectively work against headache, muscle pain, sneezing, but show no significant improvement for cough score, reduction of cold duration or total symptom score. Paracetamol has proven short-term effectiveness against nasal obstruction and relieving headache, but lacks significant effect on 
sore throat or cough [34]. Ibuprofen acts more effectively than paracetamol against sneezing and fever, but there is no clear evidence for improving respiratory symptoms [35]. As clinical data show, nasal congestion may also be effectively reduced by using decongestants, which were also commonly advised by the pharmacists in our study (in one third patient encounters). Clinical trials show small clinical effect for multi-dose of nasal decongestant in common cold treatment [36]. The use of xylometazoline in monotherapy shows clinically relevant decongestant effect [37], and intranasal application of ipratropium bromide acts against rhinorrhea, but without effectiveness against nasal congestion [38]. Combined treatment with xylometazoline and ipratropium bromide reduces both nasal congestion and rhinorrhea [37]. Furthermore, clinical trials indicate that antihistamine monotherapy has no clinical effect (especially for mid- and long-term usage) [39], but its combination with analgesics and/or decongestant show some beneficial effects in adults [16]. Also, in our study we observed that pharmacists recommended second generation anti-histamines (in 1 out of 5 cases) in a combined therapy for patients with common cold symptoms.

Analysis of clinical trial results indicate that nasal saline irrigation shows possible but unclear benefits in relieving symptoms of acute upper respiratory tract infection, but due to limited number of evidence of its effectiveness further large scale randomized clinical trials are needed [40]. Current evidence suggest that using garlic, zinc and vitamin $C$ possess rather preventive than curative effect against common cold [26-28]. A variety of tested products, statistical heterogeneity of the results between different trials and questionable clinical relevance did not allow to support recommending echinacea [29], Chinese medical herbal products [30] or Pelargonium sidoides extract [31] for common cold treatment. The results of our study indicate that despite unclear clinical relevance of herbal or homeopathic products, they were recommended by the pharmacists in 1 out of 10 cases.

There is no clinical relevance to using antibiotics [41], applying intranasal corticosteroids [42], or antihistamine monotherapy for reducing separate common cold symptoms [39]. Finally, there is no clinically relevant benefit of using antivirals in upper respiratory tract infection. In addition, currently no antiviral agent is licensed to effective use in common cold treatment [43]. Interestingly, in one-third of patient encounters the pharmacists recommended anti-viral products. Moreover, one out of three patients received mucolytics, instead of cough suppressants for cough treatment. Supplementary file 3 contains a summary of the research on the effectiveness of symptomatic common cold treatment options in adults. Taken together, this indicates that pharmacist recommendations are not always in line with current best practice recommendation. This particularly applies to recommending anti-viral products, as they are ineffective in upper respiratory tract infection, or mucolytic agents, which are usually advised for lower respiratory tract infection.

Most clinical practice guidelines of common cold treatment are country and organization specific. The most popular are the United States Center For Disease Control guidelines, which recommend treating this disease with a combination of the following medications: 1) pain relievers (non-steroidal anti-inflammatory drugs) 2) nasal decongestants (alpha-mimetics) 3) cough suppressants 4) anti-histamines 5) expectorants [44]. van Driel found similar results in their clinical review [45]. Thus, the treatment is mostly based on symptoms presented by the patient, and curative treatment is not possible [46, 47].

Presented results clearly indicate that in four out of five cases the pharmacists recommended products containing paracetamol (where two out of three were in soluble form). The most frequent choice was a combination of paracetamol, guaifenesin and phenylephrine, which seems to, at least in part, treat the most common symptoms, such as headache, rhinitis, fever and cough. While paracetamol works mainly by its anti-pain action, guaifenesin is an old expectorant agent with numerous side effects and unproven effect on cough frequency, although there is one review suggesting otherwise [48]. Phenylephrine might be effective in nasal congestion, but may also have some important adverse events $[49,50]$. The second most frequent combination was paracetamol with phenylephrine and pheniramine. In this case, the old, first generation antihistamine drug was used instead of alpha-mimetic. Pheniramine may cause several adverse events and should not be used when drugs with better safety records are available [51]. Another frequently advised combination was paracetamol with ascorbic acid and pheniramine. Ascorbic acid was an important agent in common cold treatment for years. Current data suggest that its effect is small, but might be of statistical importance, although we believe that shortening the cold duration by 1.6 days has low clinical significance [27]. There is no data suggesting its efficacy in adults [52]. One might argue that this set of old generic medication is outdated, while some active substances cause several adverse events, and several new OTC agents sold separately are available on the market $[17,35]$. However, this combination is much cheaper than NSAIDs, mucolytic or cough suppressant and alpha-mimetics sold separately (in Poland it may be 1:3 price ratio). Their drawback is that they are sold separately, and not present in combinations (at least in Poland) or in a soluble form [35, 39]. 
Furthermore, the second most important class of products was nasal decongestant, recommended in one in three patient encounters. It is in line with the papers suggesting common cold treatment [53]. Interestingly, inosines were also advised in one out of three cases. Utilizing this anti-viral agent of unproven efficacy [54], although one small study suggesting otherwise [55], is probably a result of advertising. In almost every third case the pharmacists recommended OTC mucolytics. This class of agents is prescribed in lower respiratory tract infections, chronic bronchitis, pneumonia, in patients with expectorant problems [56]. There are no reasons for utilizing mucoactive agents in upper respiratory viral infections. Their utilization in acute rhinosinusitis does not have reasonable clinical trial evidence [57]. The second generation anti-histamines are widely utilized in common cold treatment, although there are no clinical trials supporting the benefits of this approach [39]. Taken together, clinically relevant symptomatic common cold treatment should base on using analgesics (NSAIDs and paracetamol), decongestant, anti-histamines (but in combination with other classes of medications) $[44,51,54]$. This data indicates that in a number of cases the pharmacists failed to recommended products with proven clinical evidence for the effective anti-common cold treatment.

While the pharmacists claimed that their decisions were solely based on the analysis of patient history and symptoms, in most cases their treatment decisions are limited to advising soluble medication combinations. This approach seems to be based on a "one-size-fits-all" rule and does not seem to rely on patient symptoms. This opinion is supported by the fact that symptom-driven advice suggests that only fever seemed to compel the pharmacists to advise NSAIDs. The interesting scenario involves patients who reported cough as the main common cold symptom. It seems not to have changed the pharmacists' decision. Moreover, most patients did not receive any cough suppressant available over-the-counter. Dry cough is a reasonable indication to suggest such medication [58, 59]. Finally, a pharmacist has less than $5 \mathrm{~min}$ to listen to the patient and make a decision. Therefore, their decisions seem to be influenced by lack of training, lack of time to evaluate the patient, lack of awareness of evidence, and marketing strategy (pharmaceutical drug promotion and financial incentives i.e. fulfilling sale plans and target sale bonuses) $[60,61]$. In contrary, mucoactive agents are probably the most frequent medication additions advised by the pharmacists during common cold treatment. They were advised without the analysis of cough characteristics [62].
As we suggested above, pharmacist counselling is the second line (after self-medication) of treating common cold. It would be of interest to introduce more symptom-based approach (such as indicated in Mináriková et al. study [6]) to ensure that pharmacists understand the symptoms and the mechanism of common cold and acute rhinosinusitis. Moreover, we believe that some formal or informal education should also be introduced (i.e. focused on cough, its types and treatment). Safety of OTC medications also ought to be emphasized, especially their interaction with other drugs and the influence on driving and operating machinery $[63,64]$.

The study has several limitations. On the one hand, the involvement of qualified pharmacists in this study, as opposed to conducting an on-line or e-mail or phone survey, allows collecting more reliable data. However, the pharmacist counselling was not recorded in any way (i.e. by audio or audiovisual recording), therefore there is a risk of differences between the collected data and the actual state, which would suggest employing the "mystery shopper" methodology for such type of study. In addition, we are not able to check whether the pharmacists duly completed the data collection forms and whether it was done for all the patients seeking pharmacist advice on anti-common cold OTC drugs who met the criteria for inclusion to the survey. Thirdly, in our study the pharmacy counselling was provided only by the pharmacists, not including pharmacy technicians. This approach limited the collected data to only one group of pharmacy employees. Extending the study to both pharmacists and pharmacy technicians should provide more comprehensive information about pharmacist recommendations on OTC products. In addition, this would allow to compare the most commonly advised classes of medications between both groups. Finally, our study was limited to OTC anti-common cold products commonly used in Poland. Therefore, in the data collection form there was an option "other", that the pharmacists could select. However, the option did not allow the pharmacist to enter additional data about the type of product, and did not provide any additional information about the variety of the advised products, apart from those mentioned in the list. For this reason, it would be beneficial to improve the methodological approach by extending the data collection form to all commercially available preparations or to allow specific products to be listed in the "other" option.

\section{Conclusion}

Clinically relevant symptomatic common cold treatment is based on using analgesics (NSAIDs and paracetamol), decongestant, anti-histamines (but in combination with 
other classes of medications) and cough suppressants. According to our data, the most common approach for pharmacist recommendations on anti-common cold treatment was a "shotgun" approach. The pharmacists commonly made recommendations for products that lack strong evidence for efficacy (i.e. anti-viral agents) and are potentially unnecessary based on the symptom presentation. The possible explanation for the pharmacists' recommendations may include lack of training, lack of time to evaluate the patient, lack of awareness of evidence and recommendations based on pharmaceutical company promotion and financial incentives.

\section{Abbreviations}

OTC: Over-the-counter; NSAIDs: Nonsteroidal anti-inflammatory drugs; Phenylephrine HCL: Phenylephrine hydrochloride.

\section{Supplementary Information}

The online version contains supplementary material available at https://doi. org/10.1186/s12875-021-01561-2.

\section{Additional file 1. Questionnaire.}

Additional file 2: Suppl Figure 1. Searching strategy for randomized clinical trials on common cold treatment efficiency (Cochrane Library and PubMed database).

Additional file 3: Suppl Table 1. Effective, possibly effective and ineffective symptomatic common cold treatment in adults.

\section{Acknowledgements}

Not applicable.

\section{Authors' contributions}

M.P. designed questionnaire and overall study, analyzed the data, interpreted the results and wrote the manuscript. P.N.KS. analyzed the data, interpreted the results and wrote the manuscript. R.P. supervised overall study, analyzed data and critically reviewed manuscript. All authors read and approved the final manuscript.

\section{Funding}

This work was supported by Medical University of Lodz Grant

503/0-149-03/503-01-001-19-00.

\section{Availability of data and materials}

All data generated or analyzed during this study are included in this published article [and its supplementary information files]

\section{Declarations}

\section{Ethics approval and consent to participate}

The study was performed in accordance with Article 2(c) of The Directive 2001/20/EC of the European Parliament and the Council, specifying the terms of a non-investigational trial as a research, where the medical products are used, recommended or dispensed (for authorized indication) by certified personnel and the results are collected in observational manner and then analyzed by epidemiological methods. Therefore, bioethical committee approval of Medical University of Lodz was not required for the study. This study was conducted based on a self-developed questionnaire, filled by the pharmacist after a pharmacy counselling resulting in dispensing an OTC medication utilized in common cold treatment. In case of survey research, it includes minimal risk and the research involves no procedures for which written consent is required, completion of the questionnaire will be accepted as evidence of consent to participate. Therefore, this study meets the requirements for waivers of signed informed consent. All the methods were performed in accordance with ethical and scientific requirements necessary for designing conducting and collecting and analyzing of the research data.

\section{Consent for publication}

Not applicable.

\section{Competing interests}

The authors declare that they have no competing interests.

Received: 24 March 2021 Accepted: 11 October 2021

Published online: 30 October 2021

\section{References}

1. Heikkinen T, Järvinen A. The common cold. Lancet. 2003;361:51-9.

2. Common cold - Guidelines | BMJ Best Practice. https://bestpractice. bmj.com/topics/en-gb/252/guidelines. Accessed 21 Jun 2021.

3. Irwin RS, Baumann MH, Bolser DC, Boulet L-P, Braman SS, Brightling CE, et al. Diagnosis and management of cough executive summary. Chest. 2006;129(1 Suppl):1S-23S.

4. Managing common infections: quidance for primary care. GOV.UK. https://www.gov.uk/government/publications/managing-commoninfections-guidance-for-primary-care. Accessed 21 Jun 2021.

5. Raal A, Volmer D, Sõukand R, Hratkevitš S, Kalle R. Complementary treatment of the common cold and flu with medicinal plants - results from two samples of pharmacy customers in Estonia. PLoS One. 2013;8:e58642.

6. Mináriková D, Fazekaš T, Minárik P, Jurišová E. Assessment of patient counselling on the common cold treatment at Slovak community pharmacies using mystery shopping. Saudi Pharm J. 2019;27:574-83.

7. Montgomery AT, Kettis Lindblad Å, Eddby P, Söderlund E, Tully MP, Kälvemark SS. Counselling behaviour and content in a pharmaceutical care service in Swedish community pharmacies. Pharm World Sci. 2010;32:455-63.

8. Assemi M, Torres NM, Tsourounis C, Kroon LA, McCart GM. Assessment of an online consumer "ask your pharmacist" service. Ann Pharmacother. 2002;36:787-92.

9. Waszyk-Nowaczyk M, Simon M. Znaczenie porady farmaceuty w procesie samoleczenia się pacjentów; 2009. p. 3.

10. Kokane JV, Pawan S. Avhad. Role of pharmacist in health care system. J Community Health Manag. 2016:3:37-40.

11. Villako P, Volmer D, Raal A. Factors influencing purchase of and counselling about prescription and OTC medicines at community pharmacies in Tallinn. Estonia Acta Pol Pharm. 2012;69(2):335-40.

12. Elhoseeny $T A$, Ibrahem $S Z$, Abo el Ela AM. Opinion of community pharmacists on use of nonprescription medications in Alexandria, Egypt. J Egypt Public Health Assoc. 2013;88:79-84.

13. Klimek L, Schumacher H, Schütt T, Gräter H, Mueck T, Michel MC. Factors associated with efficacy of an ibuprofen/pseudoephedrine combination drug in pharmacy customers with common cold symptoms. Int J Clin Pract. 2017;71:e12907.

14. Picon PD, Costa MB, da Veiga PR, Fendt LCC, Suksteris ML, Saccilotto IC, et al. Symptomatic treatment of the common cold with a fixed-dose combination of paracetamol, chlorphenamine and phenylephrine: a randomized, placebo-controlled trial. BMC Infect Dis. 2013;13:556.

15. Maggini S, Beveridge S, Suter M. A combination of high-dose vitamin C plus zinc for the common cold. J Int Med Res. 2012;40:28-42.

16. De Sutter Al, van Driel ML, Kumar AA, Lesslar O, Skrt A. Oral antihistamine-decongestant-analgesic combinations for the common cold. Cochrane Database Syst Rev. 2012. https://doi.org/10.1002/14651858. CD004976.pub3.

17. Salisbury-Afshar E. Oral antihistamine/decongestant/analgesic combinations for the common cold. Am Fam Physician. 2012;86:812-3.

18. Pourahmad M, Sobhanian S. Effect of honey on the common cold. Arch Med Res. 2009:40:224-5.

19. Kim K-I, Hong M, Park Y-C, Lee B-J, Kim K, Kang BK, et al. Herbal medicines (Eunkyosan and Samsoeum) for treating the common cold: a 
protocol for a randomized, placebo-controlled, multicenter clinical trial. Integr Med Res. 2020;9:48-53.

20. Mousa HA-L. Prevention and treatment of influenza, influenza-like illness, and common cold by herbal, complementary, and natural therapies. J Evid-Based Complement Altern Med. 2017;22:166-74.

21. Yakoot M, Salem A. Efficacy and safety of a multiherbal formula with vitamin $C$ and zinc (Immumax) in the management of the common cold. Int J Gen Med. 2011;4:45-51.

22. Ikuta K, Hashimoto K, Kaneko H, Mori S, Ohashi K, Suzutani T. Anti-viral and anti-bacterial activities of an extract of blackcurrants ( Ribes nigrum L. ): anti-microbial activity of blackcurrants. Microbiol Immunol. 2012;56:805-9.

23. Nantz MP, Rowe CA, Muller C, Creasy R, Colee J, Khoo C, et al. Consumption of cranberry polyphenols enhances human $\gamma \delta-T$ cell proliferation and reduces the number of symptoms associated with colds and influenza: a randomized, placebo-controlled intervention study. Nutr J. 2013;12:161.

24. Di Pierro F, Rapacioli G, Ferrara T, Togni S. Use of a standardized extract from Echinacea angustifolia (Polinacea) for the prevention of respiratory tract infections. Altern Med Rev J Clin Ther. 2012;17:36-41.

25. Moyad MA, Robinson LE, Zawada ET, Kittelsrud JM, Chen D-G, Reeves SG, et al. Effects of a modified yeast supplement on cold/flu symptoms. Urol Nurs. 2008;28:50-5.

26. Lissiman E, Bhasale AL, Cohen M. Garlic for the common cold. Cochrane Database Syst Rev. 2014. https://doi.org/10.1002/14651858.CD006206. pub4.

27. Hemilä $\mathrm{H}$, Chalker E. Vitamin C for preventing and treating the common cold. Cochrane Database Syst Rev. 2013. https://doi.org/10.1002/14651 858.CD000980.pub4.

28. Marshall II. Zinc for the common cold. In: The Cochrane Collaboration, editor. Cochrane database of systematic reviews. Chichester: Wiley; 2006. p. CD001364.pub2. https://doi.org/10.1002/14651858.CD001364.pub2.

29. Karsch-Völk M, Barrett B, Kiefer D, Bauer R, Ardjomand-Woelkart K, Linde K. Echinacea for preventing and treating the common cold. Cochrane Database Syst Rev. 2014. https://doi.org/10.1002/14651858.CD000530. pub3.

30. Zhang X, Wu T, Zhang J, Yan Q, Xie L, Liu GJ. Chinese medicinal herbs for the common cold. Cochrane Database Syst Rev. 2007. https://doi.org/10. 1002/14651858.CD004782.pub2.

31. Timmer A, Günther J, Motschall E, Rücker G, Antes G, Kern WV. Pelargonium sidoides extract for treating acute respiratory tract infections. Cochrane Database Syst Rev. 2013. https://doi.org/10.1002/14651858. CD006323.pub3.

32. Arroll B. Common cold. BMJ Clin Evid. 2011;2011 https://www.ncbi.nlm. nih.gov/pmc/articles/PMC3275147/. Accessed 20 May 2021.

33. Simasek M, Blandino D. Treatment of the common cold. Am Fam Physician. 2007;75:515-20.

34. Li S, Yue J, Dong BR, Yang M, Lin X, Wu T. Acetaminophen (paracetamol) for the common cold in adults. Cochrane Database Syst Rev. 2013. https://doi.org/10.1002/14651858.CD008800.pub2.

35. Kim SY, Chang Y-J, Cho HM, Hwang Y-W, Moon YS. Non-steroidal antiinflammatory drugs for the common cold. Cochrane Database Syst Rev. 2015. https://doi.org/10.1002/14651858.CD006362.pub4.

36. Deckx L, De Sutter Al, Guo L, Mir NA, van Driel ML. Nasal decongestants in monotherapy for the common cold. Cochrane Database Syst Rev. 2016. https://doi.org/10.1002/14651858.CD009612.pub2.

37. Eccles R, Martensson K, Chen SC. Effects of intranasal xylometazoline, alone or in combination with ipratropium, in patients with common cold. Curr Med Res Opin. 2010;26:889-99.

38. AlBalawi ZH, Othman SS, AIFaleh K. Intranasal ipratropium bromide for the common cold. Cochrane Database Syst Rev. 2013. https://doi.org/10. 1002/14651858.CD008231.pub3.

39. De Sutter Al, Saraswat A, van Driel ML. Antihistamines for the common cold. Cochrane Database Syst Rev. 2015;11:CD009345.

40. King D, Mitchell B, Williams CP, Spurling GK. Saline nasal irrigation for acute upper respiratory tract infections. Cochrane Database Syst Rev. 2015. https://doi.org/10.1002/14651858.CD006821.pub3.

41. Kenealy T, Arroll B. Antibiotics for the common cold and acute purulent rhinitis. Cochrane Database Syst Rev. 2013. https://doi.org/10.1002/14651 858.CD000247.pub3.
42. Hayward G, Thompson MJ, Perera R, Del Mar CB, Glasziou PP, Heneghan CJ. Corticosteroids for the common cold. Cochrane Database Syst Rev. 2015. https://doi.org/10.1002/14651858.CD008116.pub3.

43. Jefferson T, Tyrrell D. Antivirals for the common cold. Cochrane Database Syst Rev. 2001. https://doi.org/10.1002/14651858.CD002743.pub2.

44. CDC. Adult treatment recommendations. 2019. https://www.cdc.gov/ antibiotic-use/community/for-hcp/outpatient-hcp/adult-treatment-rec html. Accessed 10 Mar 2021.

45. van Driel ML, Scheire S, Deckx L, Gevaert P, De Sutter A. What treatments are effective for common cold in adults and children? BMJ. 2018:363.

46. Ruohola A, Waris M, Allander T, Ziegler T, Heikkinen T, Ruuskanen O. Viral etiology of common cold in children, Finland. Emerg Infect Dis. 2009;15:344-6.

47. Hendley JO. Epidemiology, pathogenesis, and treatment of the common cold. Semin Pediatr Infect Dis. 1998;9:50-5.

48. Albrecht HH, Dicpinigaitis PV, Guenin EP. Role of guaifenesin in the management of chronic bronchitis and upper respiratory tract infections. Multidiscip Respir Med. 2017:12:31.

49. Kiran MD, Vakharia MP, Pawaskar LJ, Sheikh SN. Efficacy and safety of a fixed dose combination of paracetamol, chlorpheniramine maleate and phenylephrine in treatment of common cold: a phase IV, open-labelled, multi-centric study. Int J Basic Clin Pharmacol. 2018;8:34.

50. Sur DKC, Plesa ML. Chronic nonallergic rhinitis. Am Fam Physician. 2018:98:171-6.

51. DeGeorge KC, Ring DJ, Dalrymple SN. Treatment of the common cold. Am Fam Physician. 2019;100:281-9.

52. Quidel S, Gómez E, Bravo-Soto G, Ortigoza Á. What are the effects of vitamin $C$ on the duration and severity of the common cold? Medwave. 2018;18:e7260.

53. Allan GM, Arroll B. Prevention and treatment of the common cold: making sense of the evidence. Can Med Assoc J. 2014;186:190-9.

54. van Driel ML, Scheire S, Deckx L, Gevaert P, De Sutter A. What treatments are effective for common cold in adults and children? BMJ. 2018;363. https://doi.org/10.1136/bmj.k3786.

55. Waldman RH, Ganguly R. Therapeutic efficacy of inosiplex (Isoprinosine) in rhinovirus infection. Ann N Y Acad Sci. 1977:284:153-60.

56. Balsamo R, Lanata L, Egan CG. Mucoactive drugs. Eur Respir Rev. 2010;19:127-33.

57. Unuvar E, Tamay Z, Yıldız I, Toprak S, Kilıc A, Aydın S, et al. Effectiveness of erdosteine, a second generation mucolytic agent, in children with acute rhinosinusitis: a randomized, placebo controlled, double-blinded clinical study. Acta Paediatr. 2010;99:585-9.

58. Padma L. Current drugs for the treatment of dry cough. J Assoc Physicians India. 2013;61:9-13.

59. Malesker MA, Callahan-Lyon P, Ireland B, Irwin RS, Adams TM, Altman KW, et al. Pharmacologic and nonpharmacologic treatment for acute cough associated with the common cold: CHEST expert panel report. CHEST. 2017;152:1021-37.

60. Ghaibi S, Ipema H, Gabay M. ASHP guidelines on the Pharmacist's role in providing drug information. Am J Health Syst Pharm. 2015;72:573-7.

61. Grebenar D, Nham E, Likic R. Factors influencing pharmacists' over-thecounter drug recommendations. Postgrad Med J. 2020;96:144.

62. Scaglione F, Petrini O. Mucoactive agents in the therapy of upper respiratory airways infections: fair to describe them just as Mucoactive? Clin Med Insights Ear Nose Throat. 2019. https://doi.org/10.1177/1179550618 821930.

63. Eccles R. Efficacy and safety of over-the-counter analgesics in the treatment of common cold and flu. J Clin Pharm Ther. 2006;31:309-19.

64. Allen PJ, Simenson S. Management of Common Cold Symptoms with over-the-counter medications: clearing the confusion. Postgrad Med. 2013;125:73-81.

\section{Publisher's Note}

Springer Nature remains neutral with regard to jurisdictional claims in published maps and institutional affiliations. 